Pacific Journal of Mathematic 


\title{
THE BEST TWO-DIMENSIONAL DIOPHANTINE APPROXIMATION CONSTANT FOR CUBIC IRRATIONALS
}

\author{
WILLIAM W. AdAMS
}

Let $1, \beta_{1}, \beta_{2}$ be a basis of a real cubic number field $K$. Let $c_{0}=c_{0}\left(\beta_{1} \beta_{2}\right)$ be the infimum over all constants $c>0$ such that

$$
\left|q \beta_{1}-p_{1}\right|<(c / q)^{1 / 2}, \quad\left|q \beta_{2}-p_{2}\right|<(c / q)^{1 / 2}
$$

has an infinite number of solutions in integers $q>0, p_{1}, p_{2}$. Set

$$
C_{0}=\sup _{\beta_{1}, \beta_{2}} c_{0}\left(\beta_{1}, \beta_{2}\right) .
$$

The purpose of this note is to observe that combining a recent beautiful result in the geometry of numbers of $A$. C. Woods with the earlier work of the author, we obtain

TheOREM. $C_{0}=2 / 7$.

It is generally conjectured that the best 2-dimensional diophantine approximation constant is also $2 / 7$ but the result here can only be taken as further evidence for the conjecture.

The statement that $C_{0} \geqq 2 / 7$ is due to Cassels [2]. Moreover, it is shown in [1] that if $1, \beta_{1}, \beta_{2}$ is the basis of a nontotally real cubic field $K$, then

$$
c_{0}\left(\beta_{1}, \beta_{2}\right) \leqq 1 / 23^{1 / 2}<2 / 7 .
$$

Thus we may restrict our attention to totally real fields $K$. The following was also proved in [1]: for a full submodule $M \subseteq K$ (a rank 3 free $Z$-module) set

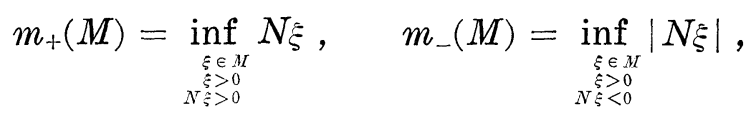

then

$$
C_{0}^{2}=\operatorname{Sup}_{K, M} \frac{4 m_{+}(M) m_{-}(M)}{D_{M}}
$$

where $D_{M}$ is the discriminant of $M$ and $N=N_{Q}^{K}$ is the norm from $K$ to $\boldsymbol{Q}$. Thus it suffices to show that for all full modules $M$ contained in a totally real cubic number field $K$, we have

$$
m_{+}(M) m_{-}(M) \leqq \frac{D_{M}}{49} .
$$


The recent result of $\mathrm{A}$. C. Woods states: if $\Lambda$ is any lattice in 3 -space of determinant $d$ then for all real numbers $u>0$ there is a point $\left(x_{1}, x_{2}, x_{3}\right)$ in $\Lambda$, not the zero point, such that

$$
-\frac{1}{u} \leqq \frac{7}{d} x_{1} x_{2} x_{3} \leqq u \quad \text { and } \quad x_{3} \geqq 0 .
$$

Embed $M$ into 3 space as usual: for $\xi \in M, \xi \rightarrow\left(\xi_{1}, \xi_{2}, \xi\right)$ where $\xi_{1}, \xi_{2}$ are the conjugates of $\xi$. The image of $M$ is a lattice $\Lambda_{M}$ of determinant $d=D_{M}^{1 / 2}$. Set, for any $\varepsilon, 0<\varepsilon<m_{+}(M), u=$ $\left(7 / D_{M}^{1 / 2}\right)\left(m_{+}(M)-\varepsilon\right)$ in Woods theorem, and we obtain a point $\xi \in M$ so that

$$
-\left(\frac{7}{D_{M}^{1 / 2}}\left(m_{+}(M)-\varepsilon\right)\right)^{-1} \leqq \frac{7}{D_{M}^{1 / 2}} N \xi \leqq \frac{7}{D_{M}^{1 / 2}}\left(m_{+}(M)-\varepsilon\right)
$$

and $\xi>0$. By definition of $m_{+}(M)$, we have $N \xi<0$ and so

$$
m_{-}(M) \leqq|N \xi| \leqq\left(\frac{1}{m_{+}(M)-\varepsilon}\right) \frac{D_{M}}{49} .
$$

Letting $\varepsilon \rightarrow 0$ we see that

$$
m_{+}(M) m_{-}(M) \leqq \frac{D_{M}}{49},
$$

thereby proving the theorem.

\section{REFERENCES}

1. W. W. Adams, Simultaneous Diophantine Approximations and Cubic Irrationales, Pacific J. Math., 30 (1969), 1-14.

2. J. W. S. Cassels, Simultaneous Diophantine Approximations, J. London Math. Soc., 30 (1955), 119-122.

3. A. C. Woods, The asymmetric product of three homogeneous linear forms, Pacific J. Math., to appear.

Received June 25, 1980.

University of Maryland

College Park, MD 


\section{PACIFIC JOURNAL OF MATHEMATICS}

\section{EDITORS}

DoNALD BABBITT (Managing Editor)

University of Galifornia

Los Angeles, California 90024

HUgo RossI

University of Utah

Salt Lake City, UT 84112

C. C. MOORE AND ANDREW OGG

University of California

Berkeley, CA 94720
J. DugunduI

Department of Mathematics

University of Southern California

Los Angeles, California 90007

R. Finn and J. Milgram

Stanford University

Stanford, California 94305

\section{ASSOCIATE EDITORS}
E. F. BeCKenbaCh
B. H. NeumanN
F. WOLF
K. YoSHIDA

\section{SUPPORTING INSTITUTIONS}

UNIVERSITY OF BRITISH COLUMBIA

CALIFORNIA INSTITUTE OF TECHNOLOGY

UNIVERSITY OF CALIFORNIA

MONTANA STATE UNIVERSITY

UNIVERSITY OF NEVADA, RENO

NEW MEXICO STATE UNIVERSITY

OREGON STATE UNIVERSITY

UNIVERSITY OF OREGON
UNIVERSITY OF SOUTHERN CALIFONIA STANFORD UNIVERSITY UNIVERSITY OF HAWAII UNIVERSITY OF TOKYO UNIVERSITY OF UTAH WASHINGTON STATE UNIVERSITY UNIVERSITY OF WASHINGTON 


\section{Pacific Journal of Mathematics}

\section{Vol. 91, No. $1 \quad$ November, 1980}

Harvey Leslie Abbott, Extremal problems on nonaveraging and nondividing

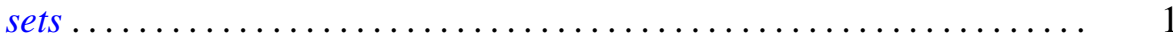

Marine Bruce Abrahamse and Stephen D. Fisher, Mapping intervals to

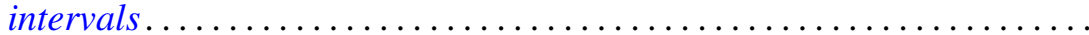

William Wells Adams, The best two-dimensional Diophantine

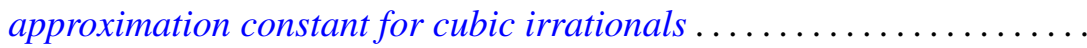

Marilyn Breen, A quantitative version of Krasnosel'skiu 's theorem in

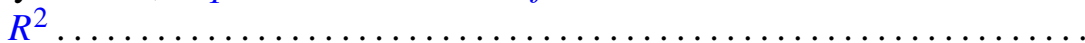

Stephen LaVern Campbell, Linear operators for which $T^{*} T$ and $T T^{*}$

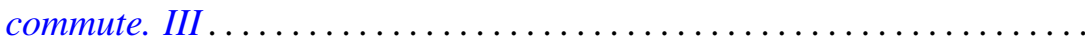

Zvonko Cerin, On cellular decompositions of Hilbert cube manifolds ......

J. R. Choike, Ignacy I. Kotlarski and V. M. Smith, On a characterization

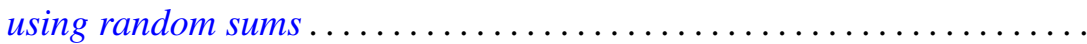

Karl-Theodor Eisele, Direct factorizations of measures .............. 79

Douglas Harris, Every space is a path component space ............. 95

John P. Holmes and Arthur Argyle Sagle, Analytic H-spaces, Campbell-Hausdorff formula, and alternative algebras.............

Richard Howard Hudson and Kenneth S. Williams, Some new residuacity criteria ..........................................

V. Karunakaran and Michael Robert Ziegler, The radius of starlikeness for a class of regular functions defined by an integral ....

Ka-Sing Lau, On the Banach spaces of functions with bounded upper

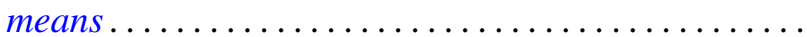

Daniel Paul Maki, On determining regular behavior from the recurrence formula for orthogonal polynomials................

Stephen Joseph McAdam, Asymptotic prime divisors and going down...

Douglas Edward Miller, Borel selectors for separated quotients ..

Kent Morrison, The scheme of finite-dimensional representations of an algebra

Donald P. Story, A characterization of the local Radon-Nikodým property by tensor products

Arne Stray, Two applications of the Schur-Nevanlinna algorithm ...

N. B. Tinberg, The Levi decomposition of a split $(B, N)$-pair ...

Charles Irvin Vinsonhaler and William Jennings Wickless, A theorem on quasi-pure-projective torsion free abelian groups of finite rank... 